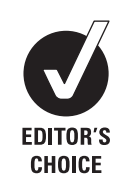

${ }^{1}$ Department of Family Medicine, University of Washington, Seattle, Washington, USA ${ }^{2}$ National Collegiate Athletic Association, Indianapolis, Indiana, USA

${ }^{3}$ Department of Family Medicine, University of Tennessee, Knoxville TN, USA

\section{Correspondence to}

Kimberly G Harmon, Departments of Family Medicine and Sports Medicine and Orthopaedics, 4060 East Stevens Circle, Hall Health Sports Medicine Clinic, University of Washington, Seattle, WA 98195, USA; kharmon@u.washington.edu

Received 23 December 2011 Accepted 10 February 2012

\title{
Sickle cell trait associated with a RR of death of 37 times in national collegiate athletic association football athletes: a database with 2 million athlete-years as the denominator
}

\author{
Kimberly G Harmon, ${ }^{1}$ Jonathan A Drezner, ${ }^{1}$ David Klossner, ${ }^{2}$ Irfan M Asif ${ }^{3}$
}

\begin{abstract}
Background This study examines sickle cell trait (SCT) as a cause of sudden death in National Collegiate Athletic Association (NCAA) athletes and explores the cost-effectiveness of different screening models. Methods The authors reviewed the cause of all cases of sudden death in NCAA student-athletes from January 2004 through December 2008. The authors also explored the cost-effectiveness of screening for this condition in selected populations assuming that identifying athletes with SCT would prevent death.

Results There were 273 deaths and a total of 1969663 athlete-participant-years. Five (2\%) deaths were associated with SCT. In football athletes, there were $72(26 \%)$ deaths. Of these, 52 (72\%) were due to trauma unrelated to sports activity and $20(28 \%)$ were due to medical causes; nine deaths were cardiac (45\%), five were associated with SCT (25\%). Thirteen of the 20 deaths due to medical causes occurred during exertion; cardiac $(6,46 \%)$ SCT associated $(5,39 \%)$, and heat stroke unrelated to SCT (2,15\%). All deaths associated with SCT occurred in black Division I football athletes. The risk of exertional death in Division I football players with SCT was 1:827 which was 37 times higher than in athletes without SCT. The cost per case identified varied widely depending on the population screened and the price of the screening test.
\end{abstract}

Conclusions Exertional death in athletes with SCT occurs at a higher rate than previously appreciated. More research is needed to (1) understand the pathophysiology of death in SCT-positive athletes and (2) determine whether screening high-risk populations reduces mortality.

\section{INTRODUCTION}

Sickle cell trait (SCT) has received significant attention as a cause of death in American football athletes. It has been cited in the medical literature as a leading cause of death in military basic training and civilian organised sport, ${ }^{1-4}$ and the lay press has characterised death in football athletes with SCT as nearly epidemic. SCT is common, with 1 in 14 (7\%) of blacks having SCT and up to 1 in 625 Caucasians carrying the gene. ${ }^{5}$ However, while SCT is common in the general population, the RR of exertional death related to SCT is unknown.

Normal haemoglobin ( $\mathrm{Hgb})$ is composed of two $\alpha$ and two $\beta$ chains. Hgb $S$ results from the substitution of a valine for glutamic acid at the sixth amino acid of the $\beta$ globin chain. Hgb S produces a haemoglobin tetramer that is poorly soluble when deoxygenated which can cause the red blood cell to form a sickle shape. Sickle cell disease occurs when an individual is homozygous for $\mathrm{Hgb} \mathrm{S}$. Vasoocclusion and haemolysis leading to sickle cell crisis are the hallmark of sickle cell disease which is generally incompatible with strenuous exercise. SCT occurs when an individual has one normal Hgb gene and one for Hgb S and is usually considered benign. Although there is an increased incidence of exertional death in those with SCT, the underlying pathophysiological mechanism is unclear.

An association of SCT with sudden death was first reported in 1970 when it was noted that a disproportionate number of deaths in military recruits training at moderate altitude were positive for SCT. ${ }^{6}$ Kark expanded on these findings reporting that the risk of sudden death in black recruits with SCT was 28 times those without SCT in a review of medical records and autopsy data. ${ }^{7}$ Other studies in military basic training have confirmed an association of sudden death with SCT. ${ }^{89}$ Concern of a similar association in athletes developed after the 1973 death of a college football player and was first addressed by an National Collegiate Athletic Association (NCAA) guideline in 1975. Despite NCAA guidelines, there have continued to be intermittent deaths related to SCT in the NCAA. There is no published literature quantifying the risk of death in NCAA athletes with SCT; however, in 2010 legislation was enacted requiring all Division I schools to screen athletes or have them sign a waiver declining the screen, if the athletes' SCT status was not already known from neonatal birth screening. This study examines SCT associated sudden death in NCAA athletes and explores the cost-effectiveness of different screening models.

\section{METHODS}

All cases of sudden death in NCAA student-athletes from January 2004 through December 2008 were examined for cause of death using a previously defined database of death in athletes. ${ }^{10}$ The database was developed using two different data sources: ${ }^{1}$ the NCAA Resolutions list and ${ }^{2}$ from the Parent Heart Watch (PHW) database. The NCAA Resolutions list is compiled annually in honorarium of NCAA student-athletes who have died of any cause and is voluntary. PHW is a notfor-profit group dedicated to the prevention and awareness of sudden cardiac arrest (SCA) in young people. They keep an ongoing database of sudden 


\section{All-Cause NCAA Deaths 2004-2008}

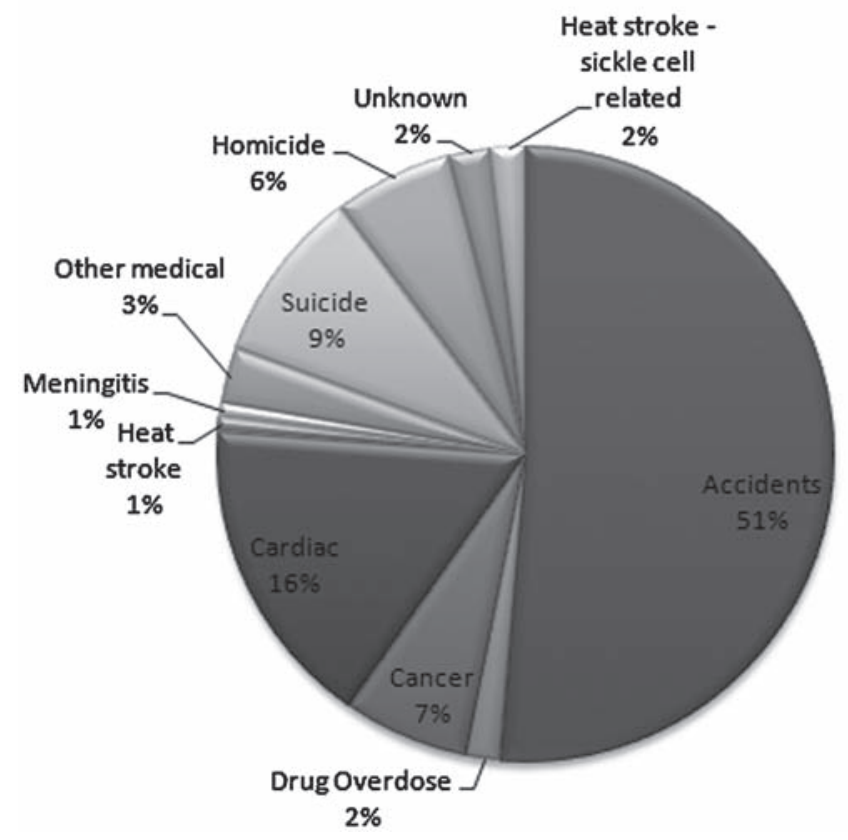

Figure 1 All-cause NCAA deaths 2004-2008.

\section{All-Cause Football Deaths 2004 - 2008}

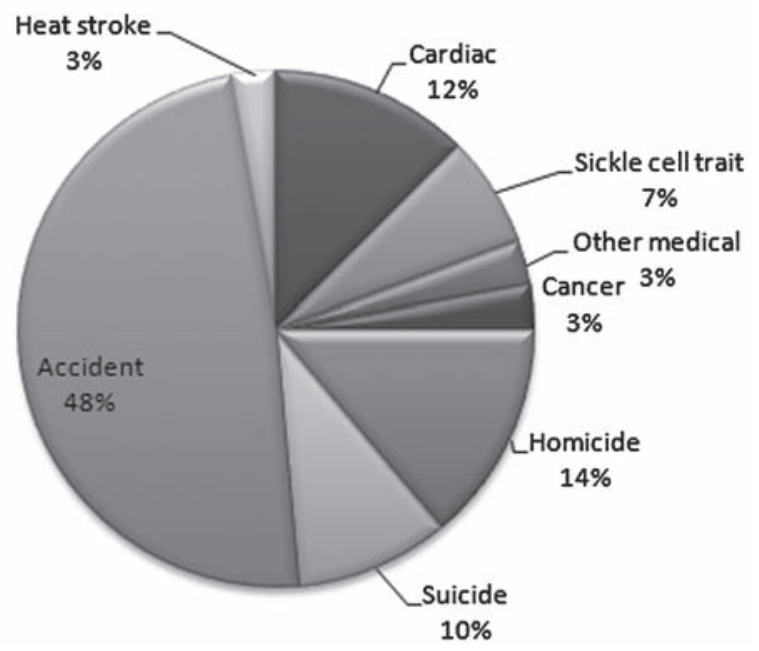

Figure 2 All-cause football deaths 2004-2008.

death and SCA in young people created from weekly internet searches. The PHW Database was reviewed, and deaths in NCAA athletes were identified and cross-referenced with the NCAA Resolutions list, which was then combined into a single database.

Missing information regarding cause of death was acquired through internet searches and media reports, reports in the NCAA News as well as emails and telephone calls to sports information directors, head athletic trainers, athletic directors and coroners. When possible, the student-athlete's parents or guardians were interviewed. The study was approved by the University of Washington Division of Human Subjects.

Demographic data in NCAA athletes were obtained from the NCAA Sport Sponsorship and Participation Rates Report ${ }^{11}$ and the NCAA Student Ethnicity Report. ${ }^{12}$ The gender and ethnic information is provided by institutions to the NCAA

\section{Exertional Football Deaths $2004-2008$}

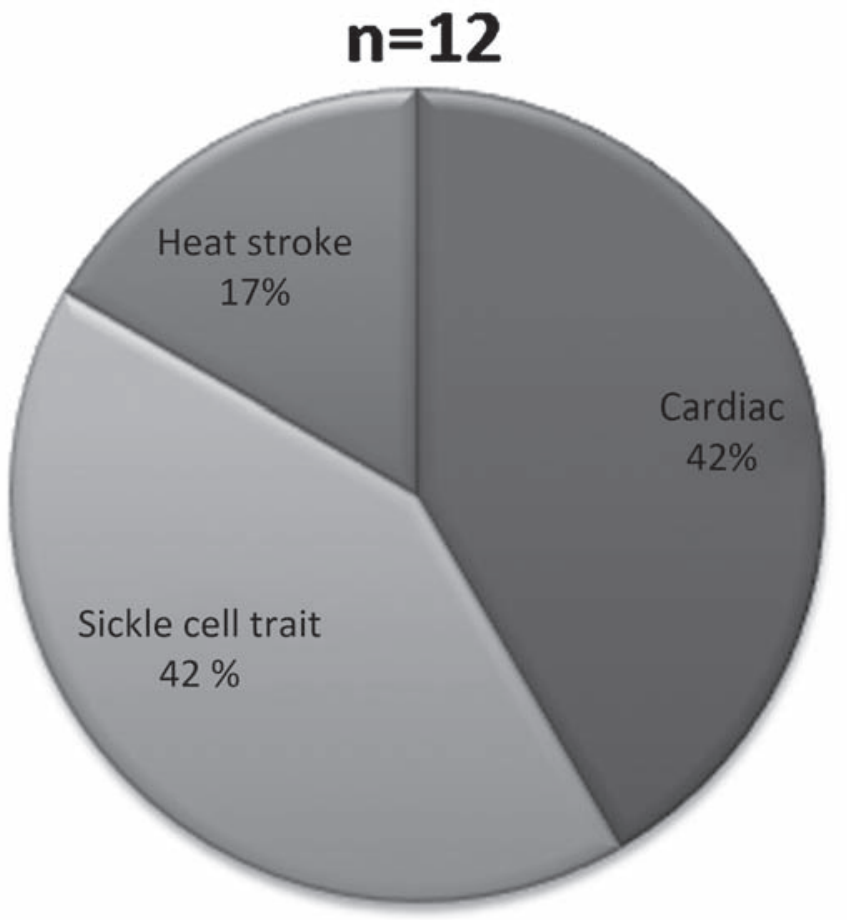

Figure 3 Exertional deaths 2004-2008; n=12.

annually, and these reports are compiled periodically by the NCAA Department of Research. The number of athletes participating overall and in football in each division was recorded. The numbers of black athletes and non-black athletes were also noted, and the numbers of those with SCT were estimated as being $7 \%$ of black athletes and $0.16 \%$ of non-black athletes (the vast majority of who were Caucasian) according to prevalence rates reported by the Centers for Disease Control (CDC). ${ }^{5}$ Death in NCAA athletes was noted and death in football athletes was examined with particular attention to death in athletes with SCT.

The cost-effectiveness of screening athletes for SCT was explored to estimate the cost per life-year gained of different screening models assuming that identification of an athlete with SCT would prevent their death. The cost of screening tests used to identify SCT varies according to the type of test as well as regional variations in cost. Three test costs were examined: ${ }^{1} \$ 5,{ }^{2} \$ 30$ and $^{3} \$ 150$. The 'simple $\$ 5$ screening test' was initially identified by the NCAA as a viable test method. Beginning in October 2011, the NCAA has contracted with a laboratory to provide screening haemoglobin solubility tests to member institutions for about $\$ 10$ and haemoglobin electrophoresis for $\sim \$ 30$. Haemoglobin electrophoresis can cost up to $\$ 150$ at some institutions. Cost-effectiveness was calculated assuming an initial start-up year when all athletes were screened. Screening in subsequent years occurred only for incoming athletes and was calculated assuming no start-up year. For simplicity, it was assumed that testing for SCT was $100 \%$ sensitive and specific and that identification of an athlete with SCT would prevent their death representing a bestcase scenario. It was also assumed that prevention of death in a college-aged athlete would afford an additional 50-year life expectancy (approximating the average life expectancy). 
Table 1 Exertional death rates with and without sickle cell trait

\section{NCAA Athletes 2004 to 2008}

\begin{tabular}{|c|c|c|c|c|c|c|c|c|}
\hline & $\begin{array}{l}\text { Number of } \\
\text { athletes } \\
2004 \text { to } 2008\end{array}$ & $\begin{array}{l}\text { Estimated } \\
\text { number of } \\
\text { athletes } \\
\text { with SCT }\end{array}$ & $\begin{array}{l}\text { Annual risk of } \\
\text { death for all } \\
\text { athletes } \\
\text { related to SCT }\end{array}$ & $\begin{array}{l}\text { Risk of } \\
\text { exertional } \\
\text { death in } \\
\text { athletes } \\
\text { with SCT }\end{array}$ & $\begin{array}{l}\text { Estimated } \\
\text { number of } \\
\text { athletes } \\
\text { without SCT }\end{array}$ & $\begin{array}{l}\text { Number of } \\
\text { exertional } \\
\text { deaths in } \\
\text { athletes } \\
\text { without SCT }\end{array}$ & $\begin{array}{l}\text { Risk of } \\
\text { exertional } \\
\text { death in athletes } \\
\text { without SCT }\end{array}$ & $\begin{array}{l}\text { RR of exertional } \\
\text { death in those } \\
\text { with SCT } \\
\text { versus those } \\
\text { without }\end{array}$ \\
\hline \multicolumn{9}{|l|}{ All ethnicities } \\
\hline All divisions, all sports & 1969663 & 23529 & 393933 & 4706 & 1946134 & 28 & 69505 & 15 \\
\hline Division I athletes all sports & 788033 & 12512 & 157607 & 2502 & 775521 & 16 & 48470 & 19 \\
\hline All divisions, football athletes & 308042 & 7432 & 61608 & 1486 & 300610 & 7 & 42944 & 29 \\
\hline Division I football athletes & 126447 & 4134 & 25289 & 827 & 122313 & 4 & 30578 & 37 \\
\hline \multicolumn{9}{|l|}{ Black athletes } \\
\hline All divisions, all sports & 297911 & 20854 & 59582 & 4171 & 277057 & 13 & 21312 & 5 \\
\hline Division I athletes all sports & 164490 & 11514 & 32898 & 2303 & 152976 & 8 & 19122 & 8 \\
\hline All divisions, football athletes & 101450 & 7102 & 20290 & 1420 & 94349 & 4 & 23587 & 17 \\
\hline Division I football athletes & 57488 & 4024 & 11498 & 805 & 53464 & 3 & 17821 & 22 \\
\hline \multicolumn{9}{|l|}{ Non-black athletes } \\
\hline All divisions, all sports & 1671752 & 2675 & - & - & 1669077 & 15 & 111272 & - \\
\hline Division I athletes all sports & 623543 & 998 & - & - & 622545 & 7 & 88935 & - \\
\hline All divisions, football athletes & 206592 & 331 & - & - & 206261 & 3 & 68754 & - \\
\hline Division I football athletes & 68959 & 110 & - & - & 68849 & 1 & 68849 & - \\
\hline
\end{tabular}

SCT, sickle cell trait;

NCAA, National Collegiate Athletic Association;

A cost per life year saved less than $\$ 50000$ was considered cost-effective.

\section{RESULTS}

During the 5-year period from 2004 to 2008, there were 273 deaths and a total of 1969663 athlete-participant-years. Five $(2 \%)$ of all deaths occurred in athletes with SCT(figure 1). Football represented 72 (26\%) of all student-athlete deaths. Of these, $52(72 \%)$ were due to trauma unrelated to sports activity and $20(28 \%)$ were due to medical causes (figure 2$)$. The leading medical cause of death in football athletes was cardiac ( 9 , $45 \%)$, followed by death associated with SCT (5, 25\%), heat stroke unrelated to SCT $(2,10 \%)$, cancer $(2,10 \%)$, diabetes (1, $5 \%$ ) and sepsis (1, 5\%). No deaths were related to head trauma or concussion. No deaths occurred during competition.

Deaths which occurred with exertion were analysed. These included deaths due to cardiac causes, heat illness and deaths associated with SCT. In football players, there were 12 exertional deaths. Of the exertional deaths, five were related to cardiac causes (42\%), five were in athletes with SCT (42\%) and two were from heat stroke in athletes without SCT (15\%) (figure 3).

All deaths in athletes with SCT occurred in black Division I football athletes during practice or conditioning. Thus, the risk of death associated with SCT in non-football athletes or non-black athletes in this cohort was zero. For those identified with SCT, the risk was quite high. Overall, the risk of exertional death associated with SCT was 1:4706 for all athletes (all sports, all divisions, all ethnicities) and 1:4171 for black athletes (all sports, all divisions). For Division I football players (all ethnicities) with SCT the risk of death was 1:827, and in black Division I football athletes with SCT the risk was 1:805 (table 1).

The RR of exertional death in athletes with SCT (all divisions, all sports) was 15 times higher than exertional death in athletes without SCT. In Division I football athletes (all ethnicities) with SCT, the risk of exertional death was 37 times greater than exertional death in those without SCT, and in black Division I football players with SCT the risk of exertional death was 22 times greater than exertional death in black players without SCT (table 1). The overall risk of exertional death from any cause was 5.2 times higher in black athletes with or without SCT compared with that in non-black athletes.

Cost-effectiveness of screening was dependent on the population screened, the price of the screening test and the assumption that identification of athletes with SCT prevents death. Four subgroups were examined; ${ }^{1}$ black football athletes (all divisions), ${ }^{2}$ football athletes (all ethnicities, all divisions), ${ }^{3}$ black athletes (all sports, all divisions) and ${ }^{4}$ all athletes (all ethnicities, all sports and all divisions). The cost estimate included a first year of screening all athletes at an institution followed by only screening incoming athletes over the 5 year study. The total cost of the programme ranged from $\$ 202900$ (black football athletes) to $\$ 119539920$ (all athletes). The cost to prevent one death over 5 years ranged from $\$ 40580$ (black football athletes) to $\$ 23907984$ (all athletes). The cost per lifeyear saved ranged from $\$ 812$ to $\$ 478160$ (table 2). Screening only incoming athletes was cost-effective in all groups if a $\$ 30$ test was used costing $\$ 2435$ per year life saved (black football athletes) to $\$ 47816$ (all athletes) (table 3).

\section{DISCUSSION}

SCT is associated with exertional death in NCAA football players with a rate of 1:827 in Division I football athletes. The death rate is 37 times higher in football athletes with SCT than those without. Death in other athletes with SCT or those undergoing strenuous physical exertion has been reported although in this cohort no other sports were represented. ${ }^{1} 489$ 13-15 The National Center for Catastrophic Sport Injury Research has documented 12 deaths association with SCT, seven of which occurred between 2000 and 2008. Other experts have cited up to 19 deaths associated with SCT in NCAA athletes since 1973 (Eichner, personal communication). All but 2 of these 19 deaths have been in Division I football players. There has been one NCAA male basketball athlete playing pick-up basketball 
Table 2 Cost-effectiveness analysis of sickle cell screening for 2004 to 2008 (including first year start-up cost)

\begin{tabular}{|c|c|c|c|c|}
\hline & Black football athletes & All football athletes & All black athletes & All athletes \\
\hline Number of athletes & 101450 & 308043 & 297911 & 1992332 \\
\hline Total screens every year after & 5073 & 15402 & 14896 & 99617 \\
\hline Total number of athletes screened in 5 years & 40580 & 123217 & 119164 & 796933 \\
\hline \multicolumn{5}{|l|}{ Cost of screening programme } \\
\hline Hgb electrophoresis $-\$ 150$ & $\$ 6087000$ & $\$ 18482580$ & $\$ 17874660$ & $\$ 119539920$ \\
\hline \multicolumn{5}{|l|}{ Cost to identify one athlete with SCT } \\
\hline 'Simple $\$ 5$ test' & $\$ 71.43$ & $\$ 207.24$ & $\$ 71.43$ & $\$ 427.35$ \\
\hline$\$ 30$ & $\$ 429$ & $\$ 1243$ & $\$ 429$ & $\$ 2564$ \\
\hline Hgb electrophoresis $-\$ 150$ & $\$ 2143$ & $\$ 6217$ & $\$ 2143$ & $\$ 12821$ \\
\hline \multicolumn{5}{|l|}{ Cost per life-year saved } \\
\hline 'Simple $\$ 5$ test' & $\$ 812$ & $\$ 2464$ & $\$ 2383$ & $\$ 15939$ \\
\hline$\$ 30$ & $\$ 4870$ & $\$ 14786$ & $\$ 14300$ & $\$ 95632$ \\
\hline Hgb electrophoresis $-\$ 150$ & $\$ 24348$ & $\$ 73930$ & $\$ 71499$ & $\$ 478160$ \\
\hline
\end{tabular}

SCT, sickle cell trait.

Table 3 Cost-effectiveness analysis sickle cell screening for 2004 to 2008 (no start-up costs with $\$ 30$ test)

\begin{tabular}{|c|c|c|c|c|}
\hline & Black football athletes & All football athletes & All black athletes & All athletes \\
\hline Total number of athletes screened in 5 years & 20290 & 61609 & 59582 & 398466 \\
\hline Cost of screening & $\$ 30$ & $\$ 30$ & $\$ 30$ & $\$ 30$ \\
\hline Cost of screening programme & $\$ 608700$ & $\$ 1848270$ & $\$ 1787460$ & $\$ 11953980$ \\
\hline Cost to identify one athlete with SCT & $\$ 429$ & $\$ 27957$ & $\$ 429$ & $\$ 22047$ \\
\hline Cost to prevent one death over 5 years & $\$ 121740$ & $\$ 369654$ & $\$ 357492$ & $\$ 2390796$ \\
\hline Cost per life-year saved & $\$ 2435$ & $\$ 7393$ & $\$ 7150$ & $\$ 47816$ \\
\hline
\end{tabular}

SCT, sickle cell trait.

and one male track athlete who have reportedly died from exertional collapse in athletes with SCT.

Although there is an association between exertional death and SCT, the pathophysiology of death is unknown. It has been proposed that a combination of high-intensity exercise, dehydration and thermal strain may induce sufficient hyperthermia, hyperosmolality, acidosis and red cell dehydration to lead to significant erythrocyte sickling, inflammation and microvascular occlusion causing exertional collapse in some exercisers with SCT. ${ }^{2}{ }^{15-18}$ Blood viscosity and adhesion properties are also altered in athletes with SCT. ${ }^{19-26}$ The proposed mechanism of death is arrhythmia caused by hyperkalaemia from muscle necrosis and altered ion channel permeability. ${ }^{12} 1618$ However, others argue that this is unlikely citing the contrast between the proposed pathophysiology and the known problems seen in people with sickle cell disease who experience sickling episodes with splenic, pulmonary and bony infarcts. Environmental factors such as exercise intensity, altitude, hydration status and concurrent illness likely play a role in the development of exertional death in SCT. There may also be other genetic co-factors which make some athletes with SCT more likely to be affected than others. ${ }^{18}$
Strategies to prevent death in those with SCT seem warranted. Restriction from play is not recommended, but instead screening and targeted interventions are needed in those with SCT. ${ }^{27} 28$ Determining the SCT status of athletes can be accomplished by reviewing previous medical history or repeat testing. All newborns are screened at birth for sickle cell disease where early interventions in those homozygous for $\mathrm{Hgb} \mathrm{S}$ have shown to positively impact health. While SCT status is also identified, this information may not be communicated and is often not recalled by the athlete or their parents. If SCT status is not known, testing can be accomplished by several methods. A haemoglobin solubility test is recommended by the NCAA at a minimum. In this test, a reagent is added to blood. Hgb $\mathrm{S}$ is insoluble compared with other haemoglobins and the blood will appear cloudy instead of clear. This test does not distinguish between sickle cell disease, SCT and other haemoglobin variants and false positives and false negatives occur. A positive test should be followed up with additional testing to confirm and further define any abnormalities. The NCAA has contracted with a national laboratory to provide this testing to NCAA institutions for less than $\$ 10$. 
Haemoglobin electrophoresis is a more accurate method to determine haemoglobin type. With electrophoresis, the haemoglobin migrates through a gel at different rates when an electrical charge is applied. Hgb electrophoresis can differentiate between different Hgb subtypes and is considered the most accurate method for identification of haemoglobinopathies. Isoelectric focusing has also been used to identify those with SCT. This test is similar to electrophoresis except the blood is run through a gel with a $\mathrm{pH}$ gradient. Electrophoresis and isoelectric focusing are considerably more expensive and more time-consuming to perform than Hgb solubility testing. Many institutions do not have the capacity to quickly perform multiple tests which can be problematic if athletic participation is restricted until SCT status is known.

From a public health perspective, screening should only be performed if there is an effective intervention. It is unclear if recommended interventions in athletes with SCT are effective. Recommended interventions include screening to identify athletes followed by education, targeted modifications of training and conditioning, an acclimatisation schedule, cessation of activity with any symptoms, and allowing SCT athletes to set their own pace. Athletes must also emphasise hydration, controlling asthma, oxygen availability at altitude and restricting workouts if he/she is ill. ${ }^{27}$ However, deaths do occur in athletes despite knowledge of sickle cell status. During the cohort studied, the status of one athlete with SCT who died $(20 \%)$ was known. In the last decade, there have been 10 exertional deaths in NCAA football players with SCT. The SCT status was known in three athletes (30\%) based on publicly available records.

The armed services have different approaches to prevention of exertional death related to SCT. The United States Navy, Marine Corps and Air Force all screen recruits for SCT. The Army does not screen for SCT status; however, in 1982 in response to the increased number of basic training deaths in SCT recruits, the US Army implemented strict hydration policies including direct observation of recruit drinking and measurement of wet bulb globe temperature with modification of training if a certain threshold was reached. During the 10 years of the study period (1982 to 1991), there were no deaths related to SCT in the intervention group (2.3 million recruits) compared with an unchanged rate of deaths in nonparticipating centres (1.2 million recruits). ${ }^{29}$ The conclusion of this study was that exertional heat illness is the predominant factor causing exercise-related deaths associated with SCT. It has also been demonstrated that exertional sickling can be prevented with adequate hydration. ${ }^{17}{ }^{30}$ Recruit deaths in the Army have increased since the initial intervention prompting the military to re-examine its policies.

\section{CONCLUSIONS}

SCT is associated with an increased risk of death in NCAA football athletes. While the most common medical cause of death in football athletes is sudden cardiac death, most athletes dying during exertion in football are positive for SCT. NCAA football players identified with SCT have an exceedingly high-risk of exertional death (1:827) that is 37 times higher than those without SCT. Screening for SCT status or signing a waiver is required of NCAA Division I athletes although the value of SCT athlete identification and targeted training modifications to reduce mortality has not been proven. If identification of athletes with SCT is effective in preventing mortality, then screening high-risk groups would be cost-effective.

\section{What this study adds}

- This study is the first study to examine the incidence of death associated with sickle cell trait (SCT) in college athletes.

- Sudden cardiac death is the leading cause of death in National Collegiate Athletic Association football athletes but SCT is an important and potentially preventable cause of death associated with exertion.

- The incidence of exertional death in athletes with SCT is 1:827.

- It is unknown whether screening prevents death associated with SCT.

Additional research is needed to understand the value of screening for SCT in NCAA athletes. Given all deaths in athletes with SCT in this cohort occurred in black Division I football athletes during practice or conditioning, it seems medically and ethically prudent to screen the highest risk group of athletes at least black Division I football players, with consideration in all black athletes and/or all football players - and target educational interventions for the player, coaches and medical staff. The value of screening in other populations, for instance high school or recreational athletes, is unknown. Strict attention to heat and hydration has been demonstrated to prevent death in US military recruits and should be heavily emphasised in football practice and conditioning. Universal attention to adequate hydration, heat mitigation practices and not continuing to push a struggling athlete should be adopted in all sports.

\section{Competing interests None.}

Ethics approval Human Subjects Division at the University of Washington.

Provenance and peer review Not commissioned; externally peer reviewed.

Data sharing statement De-identified data may be available. Requests should be made to the corresponding author.

\section{REFERENCES}

1. Eichner ER. Sickle cell trait in sports. Curr Sports Med Rep 2010;9:347-51.

2. Eichner ER. Sickle cell considerations in athletes. Clin Sports Med 2011; 30:537-49.

3. Mitchell BL. Sickle cell trait and sudden death-bringing it home. J Nat/ Med Assoc 2007;99:300-5.

4. Scheinin L, Wetli CV. Sudden death and sickle cell trait: medicolegal considerations and implications. Am J Forensic Med Pathol 2009;30:204-8.

5. Ashley-Koch A, Yang Q, Olney R. Hemoglobin S Allele and Sickle Cell Disease Centers for Disease Control, 1998.

6. Jones SR, Binder RA, Donowho EM Jr. Sudden death in sickle-cell trait. N Engl J Med 1970;282:323-5.

7. Kark JA, Posey DM, Schumacher HR, et al. Sickle-cell trait as a risk factor for sudden death in physical training. N Engl J Med 1987;317:781-7.

8. Eckart RE, Scoville SL, Campbell CL, et al. Sudden death in young adults: a 25-year review of autopsies in military recruits. Ann Intern Med 2004;141:829-34.

9. Scoville SL, Gardner JW, Magill AJ, et al. Nontraumatic deaths during U.S. Armed Forces basic training, 1977-2001. Am J Prev Med 2004;26:205-12.

10. Harmon KG, Asif IM, Klossner D, et al. Incidence of sudden cardiac death in national collegiate athletic association athletes. Circulation 2011;123:1594-600

11. DeHass D. 1981-82 - 2007-2008 NCAA Sports Sponsorship and Participation Rates Report. Indianapolis: National Collegiate Atheltic Association, 2009.

12. Zgonc E. 1999-2000 - 2008-2009 NCAA Student-Athlete Ethnicity Report. Indianapolis: National Collegiate Athletic Association, 2010.

13. Eichner ER. Sickle cell trait. J Sport Rehabil 2007;16:197-203.

14. Thogmartin JR, Wilson Cl, Palma NA, et al. Sickle cell trait-associated deaths: a case series with a review of the literature. J Forensic Sci 2011; 56:1352-60.

15. Makaryus JN, Catanzaro JN, Katona KC. Exertional rhabdomyolysis and renal failure in patients with sickle cell trait: is it time to change our approach? Hematology 2007;12:349-52. 
16. Anzalone ML, Green VS, Buja M, et al. Sickle cell trait and fatal rhabdomyolysis in football training: a case study. Med Sci Sports Exerc 2010;42:3-7.

17. Bergeron MF, Cannon JG, Hall EL, et al. Erythrocyte sickling during exercise and thermal stress. Clin J Sport Med 2004;14:354-6.

18. Loosemore M, Walsh SB, Morris E, et al. Sudden exertional death in sickle cell trait. Br J Sports Med Published Online First: 30 September 2011 doi:10.1136/ bjsports-2011-090521

19. Connes P. Hemorheology and exercise: effects of warm environments and potential consequences for sickle cell trait carriers. Scand J Med Sci Sports 2010;20 Suppl 3:48-52.

20. Connes P, Hue 0, Tripette J, et al. Blood rheology abnormalities and vascular cell adhesion mechanisms in sickle cell trait carriers during exercise. Clin Hemorheol Microcirc 2008;39:179-84.

21. Connes $\mathbf{P}$, Sara F, Hardy-Dessources MD, et al. Effects of short supramaximal exercise on hemorheology in sickle cell trait carriers. Eur J Appl Physiol 2006;97:143-50.

22. Connes P, Tripette J, Chalabi T, et al. Effects of strenuous exercise on blood coagulation activity in sickle cell trait carriers. Clin Hemorheol Microcirc 2008;38:13-21.
23. Monchanin G, Connes P, Wouassi D, et al. Hemorheology, sickle cell trait and alpha-thalassemia in athletes: effects of exercise. Med Sci Sports Exerc 2005; 37:1086-92.

24. Monchanin G, Serpero LD, Connes P, et al. Effects of progressive and maximal exercise on plasma levels of adhesion molecules in athletes with sickle cell trait with or without alpha-thalassemia. J Appl Physio/ 2007;102:169-73.

25. Tripette J, Connes P, Hedreville M, et al. Patterns of exercise-related inflammatory response in sickle cell trait carriers. Br J Sports Med 2010;44:232-7.

26. Tripette J, Hardy-Dessources MD, Sara F, et al. Does repeated and heavy exercise impair blood rheology in carriers of sickle cell trait? Clin J Sport Med 2007; 17:465-70

27. National Athletic Trainers Consensus Statement: Sickle Cell Trait and the Athlete. http://www.nata.org/NR062107 (accessed 16 Dec 2011)

28. Sickle Cell Trait and the Athelte. 2011-2012 NCAA Sports Medicine Handbook.

29. Kark JA. Sickle Cell Trait. 2000.

30. Tripette J, Loko G, Samb A, et al. Effects of hydration and dehydration on blood rheology in sickle cell trait carriers during exercise. Am J Physiol Heart Circ Physiol 2010;299:H908-14. 